\title{
ATRIBUT PRODUK YANG DIPERTIMBANGKAN DALAM PEMBELIAN KOSMETIK WARDAH DAN PENGARUHNYA PADA KEPUASAN MAHASISWA JURUSAN MANAJEMEN STIE "KBP" PADANG
}

\author{
Sesria Emita, Maria Magdalena \\ Sekolah Tinggi Ilmu Ekonomi KBP \\ Sesriaemita68@gmail.com
}

\begin{abstract}
This research has problem formulation as follows whether product attribute have an effect on student satisfaction in STIE "KBP" padang. In this research of type data used is quantitative data. The populatiion in this students study STIE "KBP" Padang which amounted to 538 people and samples 85 people using the formula slovin. Based on the results of research show that attribute product have positive and significant effect to customer satisfaction because t-hitung value $(9,678)$ with significant value 0,000 smaller than level of significance 0,05. While the F-test value of the resullt test is 93.656, and the significant value $f$ for the product attribute variable 0.000 this means significant $f$ smaller than 0.05 This indicates there is a positive and significant influence between the product attribute to consumer satisfaction.
\end{abstract}

Keywords: Product atributes, wardah cosmetics, consumer satisfaction

\section{PENDAHULUAN}

Kepuasan konsumen telah marak digunakan sebagai topik penelitian. Hal ini dikarenakan oleh saling keterkaitann antara konsep ini dengan konsep perilaku konsumen yang lainnya contoh hubungan antara kepuasan konsumen dengan kesetiaan. Kesetiaan adalah sebagai tujuan akhir perusahaan dikarenakan keyakinan untuk mempertahankan konsumen yang ada 5 kali lebih mudah dari pada memperoleh konsumen yang baru, (Erna, 2005). Bukan rahasia umum lagi banyak kaum wanita menyukai bahkan menjadi keharusan untuk melakukan perawatan tubuh bagian yang terpenting wajah. Hal ini mereka lakukan supaya kelihatan sempurna, lebih cantik dan menarik, serta sedap dipandang mata, apalagi bila dipandang oleh lawan jenis. Secara alamiah, wanita ingin terus menerus tampil cantik dan menarik dalam kesempatan apapun. Berbeda dengan kaum adam yang mayoritas tidak memikirkan masalah penampilan serta apa adanya. Di era persaingan seketat ini, suatu cara untuk memperoleh konsumen yang loyal ialah dengan memuaskan kebutuhan konsumen dengan cara yang konsisten dari waktu ke waktu. Ada Banyak strategi yang dapat dipergunakan oleh perusahaan Wardah artinya memiliki sertifikat atau izin yang halal. Adanya kandungan bahan yang aman dalam produk kosmetik Wardah, wanita bisa memakai berbagai macam kosmetik yang diinginkan asal tidak 
merugikan bagi masyarakat. (ni'mah, 2013) televisi memiliki kemampuan yang kuat demi mempengaruhi ataupun membangun terhadap persepsi khalayak yang dituju. Oleh karena itu media telivisi dan media masa lain sangat memiliki peranan yang penting dalam memperkenalkan terhadap suatu produk dan nantinya bisa menyakinkan masyarakat untuk memakai suatu produk yang ditawarkan terutama untuk produk wardah.

Produk ialah seperangkat atribut dan manfaat yang paling terpenting hingga kurang penting oleh penggunanya (Erna, 2005). Atribut dapat didefinikan sebagai karakteristik nyata dan tidak nyata (tangible dan intagible) dari produk yang dapat memberikan kepuasan subyektif atau pemuasan kebutuhan kepada konsumen. Dalam pengukuran terhadap suatu kepuasan konsumen, artinya pada atribut atau fitur produk ini memiliki peran yang sangat penting karena itu mempunyai banyak cara yang bisa digunakan oleh Peneliti untuk menentukan atribut produk, salah satunya ialah dengan menanyakan kepada konsumen atribut atau fitur apa saja yang nyatakan penting (Erna, 2005). Adapun Hasil yang didapat juga sekaligus menggambarkan harapan konsumen yang sesungguhnya terhadap kinerja produk.

Kecantikan adalah keelokan wajah -yang dimiliki pada wanita. Dengankecantikan yang dimiliki seorang wanita, menjadikan wanita tampak percaya diri dan berpenampilan menarik. Banyak terdapat cara yang digunakan oleh wanita dalam mempercantik diri adalah dengan memakai kosmetik. Dengan maksudnya telah menjadi suatu kebutuhan kaum wanita dalm kehidupan sehari-hari, Baik itu dari segi Penggunaan kosmetik untuk kepentingan berhias juga hukumnya boleh dengan syarat adalah suatu bahan yang dipakai secara halal dan suci.

Wardah adalah atribut kecantikan yang sangat banyak di pakai oleh wanita dan aman dipakai disebabkan semua produk kosmetik Wardah sudah diakui oleh LPPOMMUI sehingga produk kosmetik Wardah artinya memiliki sertifikat atau izin yang halal. Adanya kandungan bahan yang aman dalam produk kosmetik Wardah, wanita bisa memakai berbagai macam kosmetik yang diinginkan asal tidak merugikan bagi masyarakat. (ni'mah, 2013) televisi memiliki kemampuan yang kuat demi mempengaruhi ataupun membangun terhadap persepsi khalayak yang dituju. Oleh karena itu media telivisi dan media masa lain sangat memiliki peranan yang penting dalam memperkenalkan terhadap suatu produk dan nantinya bisa menyakinkan masyarakat untuk memakai suatu produk yang ditawarkan terutama untuk produk wardah.

Kosmetik wardah adalah produk yang sangat unik disebabkan produk ini memiliki keahlian yang dapat memenuhi segala kebutuhan mendasar bagi kaum wanita akan kecantikan sekaligus seringkali menjadi tujuan yang tepat untuk konsumen agar mempertegas identitas dirinya secara sosial dimata masyarakat umum (Erna, 2005). Lebih lanjutnya produk wardah ini sesungguhnya mempunyai resiko penggunaan dapat diperhatikan mengingat kandungan bahan-bahan kimia tidak selalu terjadi efek yang sama untuk setiap penggunaan konsumen bahkan bisa berakibat 
fatal jika terdapat kandungn kimia memiliki merkuri.

Produk Pelembab wardah yang juga produksi jebolan PT Paragon Technology andInnovation mempunyai image karakter positif bagi wanita yang identik dengan memakai hijab dan kosmetik untuk pertama kali yang memakai kosmetik merek halal sehingga bagi wanita muslimah tidak perlu bimbang dan aman dalam memakainya. Banyaknya Pelembab yang pasarkan di pasar era globalisasi sekarang ini banyak membuat di masa yang akan mendatang pesaing lebih semakin kompetitif serta karena konsumen memiliki banyak pilihan yang terdapat akan produk, mulai dari merek domestik sampai dan juga merek internasional yang tersedia dalam berbagai merek dan kualitas bagi konsumen juga didukung dengan harga lumayan Tinggi. Hal ini pemasar harus lebih memperhatikan baik itu dari sisi fisik dan segi manfaatnya, tetapi bagaimana seorang konsumen mendapatkan dan mengelola informasi sehingga dihasilkan informasi demi untuk bahan pertimbangannya.

Seiring dengan semakin pesatnya persaingan dalam dunia perdagangan, maka tidak heran jika merek merupakan bagian paling penting dalam meningkatkan kualitas sebuah produk yang di ciptakan oleh sebuahperusahaan. Merek bisa digunakan sebagai nilai tambah dalam mengambil margin yang lebih tinggi sehingga memperoleh laba yang memuaskan. Merek juga digunakan sebagaitanda suatu produk di kalangan masyarakatyang memilki kekuatan untuk tujuan utama produk itu diciptakan. Hal ini sesuai dengan yang dikatakan (fatimah, 2001) "Merekmemberikan nilai sehingga nilai total produkynag bermerek menjadi lebih tinggi dibandingkan produk yang dinilai semata-mata secara objektif. Merek bukan lagi kata yang hanya dihubungkan dengan produk ataus ekumpulan barang pada era perdagangan bebas sekarang ini tetapi juga proses dan strategi bisnis. Oleh karena itu, mereka mempunyai nilai atau ekuitas. Dan ekuitasmenjadi sangat penting karena nilai tersebutakan menjadi tolak ukur suatu produk yang ada dipasaran".

(Samuel, 2005) menyatakan "Kepuasan konsumen yaitu perasaan senang atau kecewa yang dapat dirasakan oleh seseorang apabila ia melakukan perbandingan antara kesannya dengan kinerja serta hasil pada produk dan juga harapan yang ada pada sesorang".Harapan konsumen dapat menjadi faktor penunjang penting dalam proses kepuasan konsumen (Erna, 2005). Kepuasan konsumen bisa tercapai dengan cara yaitu meningkatkan nilai di pikiran konsumen. Suatu produk jika dikatakan sanggup memenuhi nilai yang diharapkan konsumen ketika biaya atau upaya untuk mendapatkan produk lebih kecil daripada hasil atau manfaat yang diperolehnya.

Atribut produk adalah ciri-ciri yang dapat menjadi citra serta pendapat bagi para konsumen kepada produk, sehingga apabila ciri yang ada pada produk tersebut baik dan diterima secara baik oleh konsumen maka atribut produk tersebut diharapkan bisa menarik minat konsumen sehingga memutuskan membeli produk-produk tersebut. Apabila sebuah produk memiliki atribut atau karakter yang serasi dengan apa yang diharapkan bagi 
konsumen, maka produk tersebut akan dianggap cocok oleh konsumen. Produk yang cocok dengan keinginan tentunya akan lebih memungkinkan akan dibeli oleh konsumen.

Berdasarkan hasil pengujian hipotesis pertama diperoleh tingkat signifikan variabel atribut sebesar $0,000<a=0,05$. Hal ini beraarti signifikan t lebih kecil dari 0.05 yang menunjukkan adanya pengaruh yang positif dan siginfikan antara atribut produkdengan kepuasan konsumen secara parsial. Ini menunjukkan bahwa konsumen pada STIE "KBP" padang, merasa bahwa atribut produk merupakam suatu hal yang mempengaruhi dalam kepuasan konsumen, dengan demikian hipotesis pertama diterima.

Penelitian ini mendukung teori yang dikembangkan oleh ( Erna Ferrinadewi,2005) dimana hasil penelitiannya yaitu atribut produk yang dipertimbangkan dalam pembelian kosmetik dan pengaruhnya terhadap kepuasan konsumen.

\section{METODE PENELITIAN}

Objek dalam penelitian ini adalah dari STIE "KBP" Padang seperti data lokasi perusahaan, sejarah perusahaan, struktur organisasi serta pembagian tugas. Populasi dalam penelitian ini adalah mahasiswa STIE "KBP" Padang yang berjumlah 538 Orang. Dengan teknik Pengambilan Sampel dengan memakai teknik sampling insidental, yaitu siapa saja yang secara kebetulan/insidental bertemu dengan peneliti dapat dipakai sebagai sampel, bila dilihat orang yang secara kebetulan ditemui itu tepat sebagai sumber data. (sugiyono, 2015). Dalam pengumpulan data ini penulis melakukan pengumpulan data dengan cara sebagai berikut :

1. Observasi

Dengan mengadakan suatu pengamatan atau peninjauan langsung mengenai operasional perusahaan untuk memperoleh gambaran yang sebenarnya.

2. Kuisioner

Yaitu mengumpulkan data dengan mengajukan daftar pernyataan yang menjadi objek pembahasan dengan beberapa aspek yang terkait didalamnya yang di tujukan kepada mahasiswa jurusan STIE “KBP” Padang. 
Definisi operasional variebel penelitian

\begin{tabular}{|c|c|c|c|c|}
\hline Variabel & Definisi & Indikator & $\begin{array}{c}\text { Sumb } \\
\text { er }\end{array}$ & $\begin{array}{c}\text { Skala } \\
\text { penguk } \\
\text { uran }\end{array}$ \\
\hline $\begin{array}{l}\text { Atribut produk } \\
\text { (X) }\end{array}$ & $\begin{array}{l}\text { Atribut produk merupakan } \\
\text { salah satu hal penting yang } \\
\text { perlu diperhatikan oleh } \\
\text { perusahaan. Mengelola } \\
\text { atribut dengan baik } \\
\text { merupakan salah satu cara } \\
\text { yang paling penting untuk } \\
\text { menarik minat konsumen } \\
\text { dalam keputusan } \\
\text { pembelian produk. }\end{array}$ & $\begin{array}{ll}\text { 1. } & \text { Kualitas } \\
\text { Produk } \\
\text { 2. } & \text { Desain } \\
\text { Produk } \\
\text { 3. Pelayanan } \\
\text { Produk } \\
\text { 4. } \text { Kualitas } \\
\text { Produk }\end{array}$ & $\begin{array}{c}\text { (Samu } \\
\text { el, } \\
2005) \\
\text { (fatim } \\
\text { ah, } \\
2001 \text { ) }\end{array}$ & $\begin{array}{l}\text { Skala } \\
\text { likert }\end{array}$ \\
\hline $\begin{array}{l}\text { Kepuasan } \\
\text { konsumen (Y) }\end{array}$ & $\begin{array}{l}\text { Kepuasan merupakan } \\
\text { penilaian konsumen } \\
\text { terhadap fitur-fitur produk } \\
\text { atau jasa yang berhasil } \\
\text { memberikan pemenuhan } \\
\text { kebutuhan pada level yang } \\
\text { menyenangkan baik itu di } \\
\text { bawah maupun diatas } \\
\text { harapan. }\end{array}$ & $\begin{array}{l}\text { 1. Kesesuaia } \\
\text { n Harapan } \\
\text { 2. Minat } \\
\text { Berkunjun } \\
\text { g Kembali } \\
\text { 3. Kesedian } \\
\text { Merekome } \\
\text { ndasikan }\end{array}$ & $\begin{array}{l}\text { menur } \\
\text { ut } \\
\text { oliver } \\
(1999 \\
\quad \text { ) } \\
\text { menur } \\
\text { ut } \\
\text { tjipton } \\
\text { o } \\
(2004: \\
101)\end{array}$ & $\begin{array}{l}\text { Skala } \\
\text { likert }\end{array}$ \\
\hline
\end{tabular}

Data yang dapat diperoleh dianalisis dengan memakai analisis deskriptif dan analisis jalur (path analysis). Menurut (sugiyono, 2015) pathanalysis adalah teknik yang menganalisis hubungan sebab akibat yang interen antar variabel yang disusun berdasarkan urutan temporer dengan menggunakan koefisien jalur sebagai besaran nilaidalam menentukan besarnya pengaruh variabelexogenous terhadap variabel endogenous Analisis deskriptif digunakan untuk mendeskripsikanidentitas responden dan lokasi yang digunakan sebagai objek penelitian.
HASIL DAN PEMBAHASAN

Tabel 4.1

Distribusi Responden Berdasarkan Usia

\begin{tabular}{|l|l|l|}
\hline $\begin{array}{l}\text { Usia } \\
\text { Responde } \\
\mathrm{n}\end{array}$ & $\begin{array}{l}\text { Jumlah } \\
\text { Responde } \\
\mathrm{n}\end{array}$ & $\begin{array}{l}\text { Persentase( } \\
\%)\end{array}$ \\
\hline$>20$ & 66 & 77,6 \\
\hline$<20$ & 19 & 22,3 \\
\hline Jumlah & 85 & 100 \\
\hline \multicolumn{2}{|c|}{ Dari data diatas dapat }
\end{tabular}

dijelaskan bahwa responden terbanyak atau sebagaian responden berusia >20 yakni 66 responden (77.6) dan sisanya berusia <20 sebanyak 19 orang $(22,3)$. 
Tabel 4.2

Distribusi Responden Berdasarkan Jumlah pemakaian

\begin{tabular}{|c|c|c|}
\hline $\begin{array}{c}\text { Jumlah } \\
\text { pemakaia } \\
\mathrm{n}\end{array}$ & $\begin{array}{c}\text { Jumlah } \\
\text { Responde } \\
\mathrm{n}\end{array}$ & $\begin{array}{c}\text { Persentase( } \\
\%)\end{array}$ \\
\hline Sering & 39 & 45,8 \\
\hline 2 kali & 23 & 27,1 \\
\hline $\begin{array}{c}\text { Baru } \\
\text { pertama }\end{array}$ & 23 & 27,1 \\
\hline Jumlah & 85 & 100 \\
\hline
\end{tabular}

Dari tabel diatas diketahui bahwa responden dari produk wardah yang sering menggunakan sebanyak 39 orang $(45,8), 2$ kali menggunakan sebanyak 23 orang $(27,1)$, dan yang baru pertama menggunakan sebanyak $23(27,1)$.

Uji validitas mengukur valid tidaknya mutu kuesioner. Suatu kuesioner dikatakan valid jika pertanyaan adalah nilai corelation atau nilai $r$ hitung harus berada diatas 0,3(sugiyono,2007:2008).

Tabel 4.3

Hasil uji validitas Kepuasan Konsumen

\begin{tabular}{|l|l|l|l|}
\hline kk 4 & .737 & 0,3 & Valid \\
\hline kk 5 & .677 & 0,3 & Valid \\
\hline kk 6 & .738 & 0,3 & Valid \\
\hline kk 7 & .692 & 0,3 & Valid \\
\hline kk 8 & .413 & 0,3 & Valid \\
\hline
\end{tabular}

Dari tabel tersebut data diambil kesimpulan bahwa semua pernyataan dapat dikatakan valid karena correccted item-total correlation melebihi 0,3 sehingga dapat dilanjutkan untuk penelitian lebih lanjut.

Uji reliabilitas dilakukan terhadap item pernyataan yang dinyatakan valid. Suatu variabel dikatakan reliabel atau handal jika jawaban terhadap pernyataan selalu konsisten. Koefisien reliabilitas instrumen dimaksudkan untuk melihat konsistensi jawaban butirbutir pernyataan yang diberikan oleh responden. Reliabilitas suatu pernyataan variabel dikatakan baik jika memiliki nilai Cronbach;s Alpha $>0,6$. Penghitungan dilakukan dengan menggunakan program SPSS. Hasil olahan data dapat dilihat pada tabel 4.5.

\begin{tabular}{|l|l|l|l|}
\hline Variabel & $\begin{array}{l}\text { Corected } \\
\text { item-total } \\
\text { correlation }\end{array}$ & $\begin{array}{l}\text { Stan } \\
\text { dar }\end{array}$ & Keterangan \\
\hline Kk1 & .676 & 0,3 & Valid \\
\hline kk 2 & .685 & 0,3 & Valid \\
\hline kk 3 & .738 & 0,3 & Valid \\
\hline
\end{tabular}

Tabel 4.4

Hasil Uji Reliabilitas Variabel Aribut produk dan kepuasan konsumen

\begin{tabular}{|l|l|l|l|}
\hline No & Variabel & Cronbach' Alpha & Reliabilitas \\
\hline 1 & Atribut produk & .761 & Reliabel \\
\hline 2 & Kepusan konsumen & .774 & Reliabel \\
\hline
\end{tabular}

Dari tabel 4.5 dapat diambil kesimpulan bahwa dari uji reliabilitas dihasilkan nilai Cronbach's Alhpa untuk variabel penelitian yaitu Atribut produk, Kepuasan Konsumen lebih dari 0,6 yang memberikan hasil bahwa variabel yang diteliti memenuhi syarat konsistensi (reliabilitas). Jadi item-item pernyataan untuk variabel penelitian sebagai alat ukur dalam penelitian. Analisa Deskriptif (Uji TCR) Pada bab ini di uraikan tentang deskripsi masing-masing Variabel penelitian, baik variabel bebas maupun variabel terkait, distribusi frekuensi dari 
masing-masing variabel akan disajikan dalam tabel distribusi frekuensi. Variabel bebas pada penelitian Atribut produk sedangkan variabel terikatnya adalah kepuasan konsumen. Pada bagian berikut ini penulis akan memaparkan deskripsi masing- masing variabel penelitian. Pada tabel 4.5 disajikan hasil deskriptif variabel Atribut Produk seperti berikut ini :

Deskriptif Variabel Atribut Produk

Tabel 4.5

\begin{tabular}{|c|c|c|c|c|c|c|c|c|c|c|c|c|}
\hline $\begin{array}{l}\text { Indik } \\
\text { ator }\end{array}$ & No Item & SS & $\mathbf{S}$ & $\mathbf{N}$ & TS & STS & $\mathbf{N}$ & $\%$ & $\begin{array}{l}\text { Skor } \\
\text { total }\end{array}$ & Average & TCR & Kriteria \\
\hline & 1 & 28 & 48 & 9 & 0 & 0 & 85 & 100 & 359 & 4,22 & 84 & $\begin{array}{l}\text { Sangat } \\
\text { Baik }\end{array}$ \\
\hline & 2 & 31 & 42 & 9 & 2 & 0 & 85 & 100 & 359 & 4,22 & 84 & $\begin{array}{l}\text { Sangat } \\
\text { Baik }\end{array}$ \\
\hline & 3 & 41 & 35 & 8 & 1 & 0 & 85 & 100 & 372 & 4,37 & 88 & $\begin{array}{l}\text { Sangat } \\
\text { Baik }\end{array}$ \\
\hline & 4 & 17 & 57 & 9 & 0 & 2 & 85 & 100 & 343 & 4,03 & 81 & $\begin{array}{l}\text { Sangat } \\
\text { Baik } \\
\end{array}$ \\
\hline & 5 & 29 & 43 & 12 & 0 & 2 & 85 & 100 & 355 & 4,17 & 84 & $\begin{array}{l}\text { Sangat } \\
\text { Baik }\end{array}$ \\
\hline & 6 & 23 & 47 & 13 & 2 & 0 & 85 & 100 & 348 & 4,09 & 82 & $\begin{array}{l}\text { Sangat } \\
\text { Baik }\end{array}$ \\
\hline & 7 & 14 & 51 & 15 & 4 & 1 & 85 & 100 & 336 & 3,88 & 79 & baik \\
\hline & 8 & 15 & 40 & 15 & 12 & 3 & 85 & 100 & 306 & 3,60 & 72 & baik \\
\hline & & & & & & & & & & & 82 & $\begin{array}{l}\text { Sangat } \\
\text { baik }\end{array}$ \\
\hline
\end{tabular}

Berdasarkan Tabel 4,6 diatas diketahui bahwa terdapat 2 butir pernyataan yang termasuk kriteria sangat baik, dari tabel 4,6 diatas diketahui bahwa nilai terendah terdapat pada pernyataan no 8 dengan nilai TCR nya $72 \%$, hasil rata-rata TCR 82\%. Secara keseluruhan Atribut Produk dikategorikan sangat baik. Pada tabel 4.7 disajikan hasil deskriptif variabel Atribut Produk seperti berikut ini :

\section{Descriptif Variabel Kepuasan Konsumen}

Tabel 4.6

\begin{tabular}{|l|l|l|l|l|l|l|l|l|l|l|l|l|}
\hline Indikator & $\begin{array}{l}\text { No } \\
\text { Item }\end{array}$ & SS & $\mathbf{S}$ & $\mathbf{N}$ & $\mathbf{T S}$ & $\begin{array}{l}\mathbf{S} \\
\mathbf{T} \\
\mathbf{S}\end{array}$ & $\mathbf{N}$ & $\mathbf{\%}$ & $\begin{array}{l}\text { Skor } \\
\text { total }\end{array}$ & $\begin{array}{l}\text { Rata- } \\
\text { rata }\end{array}$ & $\begin{array}{l}\text { TC } \\
\mathbf{R}\end{array}$ & Kriteria \\
\hline & 1 & 17 & 50 & 13 & 5 & 0 & 85 & 100 & 335 & 3,94 & 79 & Baik \\
\hline & 2 & 23 & 48 & 13 & 1 & 0 & 85 & 100 & 357 & 4,10 & 84 & Sangat baik \\
\hline & 3 & 21 & 41 & 20 & 3 & 0 & 85 & 100 & 312 & 3,95 & 73 & baik \\
\hline & 4 & 15 & 41 & 24 & 5 & 0 & 85 & 100 & 309 & 3,78 & 73 & Baik \\
\hline & 5 & 32 & 42 & 8 & 3 & 0 & 85 & 100 & 359 & 4,18 & 84 & Sangat Baik \\
\hline & 6 & 15 & 38 & 29 & 3 & 0 & 85 & 100 & 324 & 3,77 & 76 & Baik \\
\hline & 7 & 25 & 47 & 11 & 2 & 0 & 85 & 100 & 358 & 4,11 & 84 & Sangat baik \\
\hline & 8 & 44 & 34 & 7 & 0 & 0 & 85 & 100 & 376 & 4,42 & 88 & Sangat baik \\
\hline Rata-Rata & & & & & & & & & & & 80 & Baik \\
\hline
\end{tabular}


Berdasarkan tabel 4,6 diatas dapat diketahui bahwa terdapat 4 butir pernyataan yang termasuk kriteria sangat baik dan 4 butir pernyataan yang termasuk kriteria baik, dan dari tabel 4.6 diatas diketahui bahwa nilai terendah terdapat pada pernyataan no 3 dan 4 dengan nilai TCR sebesar $73 \%$. Hasil ratarata TCR $80 \%$, dan secara keseluruhan kepuasan konsumen bisa dikatakan kriteria baik.

\section{SIMPULAN DAN SARAN}

Berdasarkan analisa dan interprestasi yang telah disampaikan pada bab sebelumnya, maka dapat dikemukakan beberapa kesimpulan darai hasil penelitian ini sebagai berikut : Dalam uji t untuk Atribut produk terhadap Kepuasan Konsumen sebesar 9.893 dengan nilai signifikan sebesar .000 . Hal ini menunjukkan pengaruh negatif dan tidak signifikan ( $9.893>0,05)$. Sehingga menolak hipotesis H1 yang menyatakan Atribut Produk berpengaruh positif dan signifikan terhadap Kepuasan mahasiswa jurusan manajemen AKBP-STIE "KBP". Dari nilai R square (R2) sebesar 0,541 hal ini berarti $54,1 \%$ variabel atribut produk (Y) akan dipengaruhi oleh variabel bebasnya yaitu Kepuasan konsumen. sedangkan sisanya $46,9 \%$ atribut produk dipengaruhi oleh variabelvariabel lainnya yang tidak diteliti dalam penelitian ini. Dalam uji $\mathrm{T}$ dapat disimpulkan adanya pengaruh yang signifikan secara parsial dan simultan antara variabel atribut produk terhadap kepuasan mahasiswa di kampus AKBP-STIE "KBP" Padang. Berdasarkan Kepada kesimpulan penelitian yang telah dilakukan maka diajukan beberapa saran yang dapat memberikan manfaat positif antara lain sebagai berikut : Diharapkan kepada peneliti selanjutnya untuk dapat menggunakan penelitian ini dengan jumlah sampel 85 orang sebagai memberikan izin kepada peneliti untuk pengambilan dan referensi yang nantinya akan memberikan perbandingan dalam melakukan penelitian pada bidang yang sama dimasa akan datang. Bagi peneliti agar dapat mengkaji lebih dalam wawasan dan pendalaman pengetahuan kepuasan konsumen khususnya yang berkaitan dengan mengetahui atribut produk yang dipertimbangkan dalam pembelian kosmetik wardah dan pengaruhnya terhadap kepuasan konsumen pada Mahasiswa STIE"KBP" Padang. Bagi penelti selanjutnya disarankan untuk mampu mencoba meperbanyak jumlah responden dan lebih selektif dalam memilih calom, responden, saran ini penting untuk meningkatkan mutu dan kualitas hasill penelitian.

\section{UCAPAN TERIMA KASIH}

Dengan selesainya dalam artikel penulis ini, penulis mengucapkan terima kasih kepada pihak-pihak yang telah membantu selama proses penulisan ini. kepada Yth: Bapak Febryandhie Ananda, SE, MSi selaku ketua STIE 'KBP', Padang. Ibu Febsri Susanti, SEI,MM selaku ketua Program Studi Manajemen yang telah mengarahkan penulis kepada yang lebih baik. Ibu Maria Magdalena, S.Pd., MM selaku Pembimbing Akademik yang telah memberikan bimbingan dan arahan kepada penulis. Ibu Maria Magdalena, S.Pd., MM. selaku Pembimbing Proposal yang telah pengumpulan data dalam penelitian ini. 


\section{DAFTAR PUSTAKA}

Dona, E. (2015). Pengaruh Brand Awareness, Perceived Quality Dan Brand Association Terhadap Keputusan Pembelian Ulang Smartphone Advan Di Kota Padang. Jurmak, 47-60.

Erna, F. (2005). Atribut Produk Yang Dipertimbangkan Dalam Pembelian Kosmetik Dan Pengaruhnya Pada Kepuasan Konsumen Di Surabaya. Jurnal Manajemen Dan Kewirausahaan, 7, pp.139-151. Retrieved from http://puslit2.petra.ac.id/ejournal/index.php/man/article/view/16360

ni'mah, nafisatun. (2013). analisis pengaruh iklan kosmetik wardah ditelevisi swasta sctv terhadap minat beli siswi jurusan tata kecantikan di smk negeri 3 pekan baru.

fatimah, siti. (2001). pengaruh kesadaran merek, persepsi kualitas, asosiasi merek terhadap keputusan pembelian pelembab wardah pada konsumen al yasini mart wonorejo.

Samuel, H. (2005). Pengaruh Kepuasan Konsumen Terhadap Kesetian Merek ( Studi Kasus Restoran The Prime Steak \& Ribs Surabaya ). Pemasaran, 74-82.

Kusmayasari, Kumadji, S., \& Kusumawati, A. (2014). Pengaruh Atribut Produk Terhadap Keputusan Pembelian Dan Kepuasan Konsumen Green Product (Survei pada Konsumen Sariayu Martha Tilaar yang Tergabung dalam Followers Official Account Twitter @Sariayu_MT).Jurnal Administrasi Bisnis, 14(1), 1-10.

Handayani, W., Ekonomi, F., \& Gunadarma, U. (2013). Pendahuluan Rumusan Masalah.

Hidayati, R. R., \& Marlius, D. (2018). Aktivitas Promosi Dalam Meningkatkan Dana Pihak Ketiga Pada PT. Bank Perkreditan Rakyat (BPR) Batang Kapas Pesisir Selatan. https://doi.org/10.31227/osf.io/8dgqn

Kusmayasari, Kumadji, S., \& Kusumawati, A. (2014). PENGARUH ATRIBUT PRODUK TERHADAP KEPUTUSAN PEMBELIAN DAN KEPUASAN KONSUMEN GREEN PRODUCT (Survei pada Konsumen Sariayu Martha Tilaar yang Tergabung dalam Followers Official Account Twitter @Sariayu_MT).Jurnal Administrasi Bisnis, 14(1), 1-10.

Marlius, D. Putriani, I. (2019). Kepuasan Nasabah PT. Bank Rakyat Indonesia Unit Tapan Cabang Painan Dilihat dari Kualitas Layanan Customer Service. Jurnal Pundi. Volume 3. No. 2. Hal.111-122. https://doi.org/10.31575/jp.v3i2.151

Marlius, D. Ananda, F. (2019). Pengaruh Kualitas Pelayanan Website Akademik Terhadap Minat Kuliah di AKBP Padang. Jurnal Pundi, Vol. 03, No. 03. Hal. 191-204. https://doi.org/10.31575/jp.v3i3.190

Marlius, D. (2017). Keputusan Pembelian Berdasarkan Faktor Psikologis Dan Bauran Pemasaran Pada PT. Intercom Mobilindo Padang. Jurnal Pundi. Volume 1. No. 1. Hal. 57-66. https://doi.org/10.31575/jp.v1i1.9

Marlius, D. (2016). Pengaruh Bauran Pemasaran Jasa Terhadap Minat Nasabah Dalam Menabung Pada Bank Nagari Cabang Muaralabuh. https://doi.org/10.31227/osf.io/vdqgx 
Marlius, D. (2018). Loyalitas Nasabah Bank Nagari Syariah Cabang Bukittinggi Dilihat Dari Kualitas Pelayanan. Jurnal Pundi. Volume 1. No. 3. Hal.1222. https://doi.org/10.31575/jp.v1i3.60

Marlius, D. (2018). Pengaruh Dimensi Kualitas Pelayanan Website Akademik Terhadap Kepuasan Mahasiswa Pada STIE "KBP”. Jurnal Ipteks Terapan. Volume 12. No. 2. Hal. 116-128. http://doi.org/10.22216/jit.2018.v12i2.633

Marlius, D. RD Putra. (2018). Strategi Pengembangan Sulam Bayang. Jurnal Benefita: Ekonomi Pembangunan Manajemen Bisnis Dan Akuntansi. Volume 3. No. 2. Hal. 204-218. http://doi.org/10.22216/jbe.v3i2.3494

Mayliza, R. (2019). Analisis Keputusan Pembelian Ulang Axis Ditinjau Dari Bauran Pemasaran Kasus Di Kota Padang. https://doi.org/10.31219/osf.io/e7xhy

Susanti, F. (2015). Pengaruh Bauran Promosi Terhadap Keputusan Klien Dalam Memilih Radio Carano Sebagai Media Promosi Iklan. https://doi.org/10.31227/osf.io/b9ws7

sugiyono. (2015). statistik non parametris. bandung. 